\title{
Literasi bank sampah dan asuransi sampah sebagai upaya peningkatan kesejahteraan masyarakat
}

\section{Nurika Restuningdiah ${ }^{1}$, Primasa Minerva Nagari ${ }^{2 \star}$, Fatma Dwi Jati $^{3}$, Aulia Azzardina $^{4}$}

${ }^{1}$ Universitas Negeri Malang, Indonesia, email: nurika.restuningdiah.fe@um.ac.id

${ }^{2}$ Universitas Negeri Malang, Indonesia, email: primasa.minerva.fe@um.ac.id

${ }^{3}$ Universitas Negeri Malang, Indonesia, email: fatma.dwi.fe@um.ac.id

${ }^{4}$ Universitas Negeri Malang, Indonesia, email: aulia.azzardina.fe@um.ac.id

*Koresponden penulis

\section{Info Artikel}

Diajukan: 19 Nov 2020

Diterima: 27 Feb 2021

Diterbitkan: 08 Mar 2021

Keywords:

waste bank; waste

insurance; waste; zero-

waste

Kata Kunci:

bank sampah; asuransi sampah; sampah; zero waste

Lisensi:

cc-by-sa

\section{Abstract}

Indonesia is the second largest contributor to plastic waste after China. Despite the regulation, waste management in Indonesia has not met the standards of waste management that are environmentally sound. This forfeits the benefits of the waste management itself and brings negative impacts on public health and environment. This condition is aggravated by the costly access towards health facility. For this reason, socialization regarding waste management is needed. In addition, this program is equipped with an introduction towards waste bank and waste insurance as a practical solution. The existence of both options are expected to solve the problem of waste and health services for the community. The program aimed to help residents of RW 014 Kelurahan Tulusrejo, Malang City to comprehend the types of waste, separation of waste by category, impact on health, recycling and other details. The meetings were carried out twice from March to October 2020. The result of the agenda is that the residents continue to process waste using composter and are expected to form an independent waste bank management for local residents. Further, they are encouraged to learn more about waste insurance to manage the local waste in a more environment friendly manner.

\footnotetext{
Abstrak

Indonesia merupakan penyumbang sampah plastik terbesar kedua setelah China. Meski ada regulasi, pengelolaan sampah di Indonesia belum memenuhi standar pengelolaan sampah yang berwawasan lingkungan. Hal ini menghilangkan manfaat dari pengelolaan sampah itu sendiri dan membawa dampak negatif bagi kesehatan masyarakat dan lingkungan. Kondisi ini diperparah dengan mahalnya akses ke fasilitas kesehatan. Untuk itu perlu adanya sosialisasi tentang pengelolaan sampah. Selain itu, agenda ini dilengkapi dengan pengenalan bank sampah dan asuransi sampah sebagai solusi praktis. Keberadaan bank sampah dan asuransi sampah diharapkan dapat mengatasi permasalahan persampahan dan pelayanan kesehatan bagi masyarakat. Pendidikan ini mencakup teori dan penerapannya; jenis sampah, pemisahan sampah menurut kategori, dampak terhadap kesehatan, daur ulang dan upaya lain yang diperlukan. Penyuluhan ini diberikan kepada warga RW 014 Kelurahan Tulusrejo. Kegiatan ini dilaksanakan mulai Maret hingga Oktober 2020. Kegiatan sosialisasi dan penyuluhan dilakukan dalam dua kali kunjungan. Hasil dari kegiatan ini adalah warga RW 014
} 
Kelurahan Tulusrejo Kota Malang akan terus mengolah sampah dengan menggunakan komposter dan ingin membentuk pengelola bank sampah yang mandiri bagi warga sekitar, juga ingin mendalami asuransi sampah agar sampah warga bisa lebih mendalam. juga bisa bermanfaat dari berbagai sudut.

\section{PENDAHULUAN}

Circular economy dan efisiensi sumber daya telah menarik banyak perhatian sebagai solusi atas kelangkaan sumber daya global (Sahimaa et al., 2017). Sampah adalah simbol inefisiensi dari lingkungan modern dan representasi dari ketidaktepatan sumber daya (Zaman \& Lehmann, 2013). Sampah dalam undang-undang didefinisikan sebagai sisa kegiatan sehari-hari manusia dan/atau proses alam yang berbentuk padat dan penghasil sampah adalah setiap orang dan/atau akibat proses alam yang menghasilkan timbulan sampah (Undang-undang Republik Indonesia Nomor 18 Tahun 2008 Tentang Pengelolaan Sampah, n.d.). Salah satu jenis sampah padat adalah plastik yang merepresentasikan bagian yang mendasar dan penting dalam ekonomi global baik secara fungsional maupun sisi biaya yang belum tergantikan oleh jenis lainnya (Garofalo, Di Maio, Scarfato, Di Gregorio, \& Incarnato, 2018). Tidak hanya plastik, pengemasan berlapis juga telah banyak digunakan untuk menjaga kualitas makanan dan produk lain meski kemudian menimbulkan masalah lingkungan yang serius (Cervantes-Reyes et al., 2015). Emisi plastik yang banyak ditimbulkan industri-industri besar sejak tahun 2010 (Dobrovszky, 2018) juga mempengaruhi volume sampah rumah tangga akibat konsumsi yang dilakukan. Pengelolaan sampah rumah tangga diatur dalam (Peraturan Pemerintah Republik Indonesia Nomor 81 tahun 2012 Tentang Pengelolaan Sampah Rumah Tangga dan Sampah Sejenis Sampah Rumah Tangga, n.d.) Sampah rumah tangga adalah sampah yang berasal dari kegiatan sehari-hari dalam rumah tangga yang tidak termasuk tinja dan sampah spesifik (Peraturan Pemerintah Republik Indonesia Nomor 81 tahun 2012 Tentang Pengelolaan Sampah Rumah Tangga dan Sampah Sejenis Sampah Rumah Tangga, n.d.) Pengelolaan sampah ini bertujuan untuk meningkatkan kesehatan masyarakat dan kualitas lingkungan serta menjadikan sampah sebagai sumber daya (Undang-undang Republik Indonesia Nomor 18 Tahun 2008 Tentang Pengelolaan Sampah).

Pemerintah dan Pemerintahan Daerah bertugas menjamin terselenggaranya pengelolaan sampah yang baik dan berwawasan lingkungan sesuai dengan tujuan sebagaimana dimaksud dalam UndangUndang ini (Undang-undang Republik Indonesia Nomor 18 Tahun 2008 Tentang Pengelolaan Sampah, n.d.). Meski telah diatur, penerapan sesuai Undang-Undang dan peraturan pelaksana ini mengalami berbagai tunggakan (Indonesian Center for Environmental Law (ICEL), 2019). Isu terkait sampah saat ini tengah mengemuka sejak terungkapnya beragam kasus sampah plastik yang meracuni biota laut dan sungai. Pada awal tahun 2020, Jakarta mengalami banjir besar yang disebabkan oleh pendangkalan sungai, volume sampah yang tinggi, dan kurangnya daerah resapan air hujan (CNN, n.d.; Kompas, n.d.) . Menteri Kelautan dan Perikanan Indonesia periode 2014- 
2019, Susi Pudjiastuti menyatakan bahwa Indonesia merupakan penyumbang sampah plastik terbesar kedua setelah China (Tempo, 2019).

Di Kota Malang, produksi sampah mencapai lebih dari 600 ton per hari. Sampah tersebut dikumpulkan di tempat pemrosesan akhir (TPA) Supit Urang yang merupakan TPA satu-satunya di Kota Malang. Sejak tahun 2018 tercatat telah beberapa kali terjadi kebakaran di TPA tersebut yang mengakibatkan pencemaran udara di wilayah sekitarnya. Tidak hanya ancaman kebakaran, volume sampah yang sangat besar dapat berdampak secara luas. Pertama, air lindi yang dihasilkan dari sampah organik yang tidak diolah dengan benar dapat meresap ke tanah dan mencemari air tanah. Air tanah yang tercemar tidak bisa lagi digunakan sehingga masyarakat terdampak harus mengeluarkan biaya lebih besar untuk mendapatkan air yang layak konsumsi untuk kebutuhan sehari-hari. Berikutnya, sampah anorganik, misalnya plastik, seiring berjalannya waktu akan hancur menjadi menjadi mikroplastik, yaitu serpihan plastik berukuran sangat kecil hingga tidak bisa dilihat oleh mata tanpa bantuan alat khusus. Mikroplastik jika tercampur ke sumber air maupun perairan akan dikonsumsi oleh hewan air yang kemudian dikonsumsi manusia. Dalam jangka panjang, ini akan menyebabkan berbagai penyakit yang berbahaya. Terakhir, gunungan sampah di TPA dapat mengancam jiwa masyarakat yang tinggal di sekitarnya karena gunungan sampah tersebut tidak stabil dan sewaktu-waktu bisa longsor dan menimbun daerah di sekitarnya. Walikota Malang mengungkapkan bahwa pemerintah kota (Pemkot) Malang harus menganggarkan Rp90 miliar setiap tahun untuk penanganan sampah. Bahkan, Pemkot Malang bekerja sama dengan Jerman menggelontorkan dana senilai Rp200 miliar untuk memperluas luas TPA Supit Urang dari sebesar 30 hektar menjadi 40 hektar (Kumparan, n.d.). Namun demikian, jumlah dana yang besar tersebut belum berhasil menyelesaikan masalah sampah. Diperlukan perubahan mindset masyarakat terkait pola konsumsi dan sampah yang dihasilkan dari aktivitas konsumsi tersebut. Pada tahun 2017, sekitar $40 \%$ total sampah yang menjadi timbunan di tempat pemrosesan akhir (TPA) merupakan sampah yang bersumber dari rumah tangga (Wardhani, 2019).

Pengelolaan sampah secara mandiri sejak di tingkat rumah tangga akan sangat membantu mengurangi masalah sampah. Sampah organik dapat diolah menjadi kompos sedangkan sampah anorganik perlu dipilah. Sampah anorganik yang memiliki nilai ekonomis dapat disalurkan ke bank sampah dan/atau asuransi sampah untuk kemudian diambil manfaatnya oleh masyarakat. Presiden Republik Indonesia, melalui Undang-Undang Republik Indonesia Nomor 18 Tahun 2018 tentang Pengelolaan Sampah, menimbang bahwa pengelolaan sampah selama ini belum sesuai dengan metode dan teknik pengelolaan sampah yang berwawasan lingkungan sehingga menimbulkan dampak negatif terhadap kesehatan masyarakat dan lingkungan (Undang-undang Republik Indonesia Nomor 18 Tahun 2008 Tentang Pengelolaan Sampah, n.d.). Juga, bahwa dalam pengelolaan sampah diperlukan kepastian hukum, kejelasan tanggung jawab dan kewenangan Pemerintah, Pemerintah Daerah, serta peran masyarakat dan dunia usaha 
sehingga pengelolaan sampah dapat berjalan secara proporsional, efektif, dan efisien (Undang-undang Republik Indonesia Nomor 18 Tahun 2008 Tentang Pengelolaan Sampah, n.d.). Proporsi pengelolaan sampah dipetakan menjadi enam cara; diangkut, ditanam, dibuat kompos, dibakar, dibuang ke kali/selokan, dibuang ke sembarang tempat (Badan Penelitian dan Pengembangan Kesehatan Kementerian Kesehatan Republik Indonesia, 2013)

Pengelolaan sampah yang baik mencakup pengangkutan oleh petugas atau anggota rumah tangga, ditanam di tanah atau dibuat kompos. Sudibyo, Pradana, Budiman, \& Budhijanto (2017), melakukan penelitian tentang manajemen sampah padat kota di Indonesia yang datanya diambil dari Tempat Pengelolaan Sampah Terpadu (TPST) di Yogyakarta. Studi tersebut berusaha menemukan solusi yang paling sesuai di antara dua solusi yang ditawarkan; pengoperasian TPST tanpa pengurangan sampah dari sumbernya dan pengoperasian TPST dibarengi dengan pengurangan sampah organik dari sumbernya. Hasilnya, skenario kedua merupakan skenario yang terbaik untuk diterapkan (Sudibyo et al., 2017). Hal ini sejalan dengan konsep zero-wastea lifestyle atau gaya hidup minim sampah. Konsep ini merupakan konsep yang paling visioner dalam menyelesaikan masalah sampah (Zaman \& Lehmann, 2013) dan telah dikembangkan dan diimplementasikan oleh beragam sektor industri dan pembuat kebijakan (Zaman, 2015).

Berdasarkan pemaparan masalah-masalah tersebut, tim Pengabdian kepada Masyarakat Fakultas Ekonomi Universitas Negeri Malang (Abdimas FE UM) akan melakukan kegiatan pengabdian kepada masyarakat dengan judul "Literasi Bank Sampah dan Asuransi Sampah sebagai Upaya Peningkatan Kesejahteraan Masyarakat".

\section{METODE PELAKSANAAN}

Kegiatan ini diawali dengan identifikasi sasaran, yaitu lingkungan tinggal RW 014 sebagai mitra program. Dengan mempertimbangkan situasi pandemi, diskusi pra-literasi dilakukan secara daring untuk mendiskusikan kebutuhan warga dan kemampuan tim pengabdian untuk menjembatani penyelesaian masalah. Diskusi tersebut menghasilkan simpulan bahwa literasi pengelolaan sampah anorganik juga diperlukan, setelah pada tahun sebelumnya kedua pihak telah bekerjasama dalam praktik pemanfaatan biopori untuk mengelola sampah organik. Untuk itu, literasi bank sampah dan asuransi sampah dipiliha sebagai materi literasi karena kesesuainnya dengan kebutuhan sasaran.

Setelah mengetahui masalah pengelolaan sampah yang dihadapi oleh sasaran, tim pengabdian FE UM menyusun rerangka sajian materi yang dirasa sesuai dengan kebutuhan warga. Selanjutnya, tim menentukan dan menghubungi narasumber untuk mengetahui kesediaan narasumber terkait penyajian materi, waktu dan target tim. Setelah para narasumber; Ibu Ullifatul Muyassaro dan Bapak Ruliyanto Ratno Saputro bersedia untuk terlibat dalam agenda ini, tim berdiskusi bersama keduanya untuk meramu bahan sajian dan teknis literasi bank sampah dan asuransi sampah. 
Dalam diskusi tersebut, kedua narasumber memaparkan kelebihan dan kekurangan bank sampah dan asuransi sampah. Pasca berdiskusi, tim dapat menyimpulkan bahwa pendirian bank sampah dan asuransi sampah dapat memberikan banyak dampak positif bagi masyarakat, alam dan pemerintah. Masyarakat memperoleh manfaat berupa sejumlah uang atau layanan kesehatan gratis sebagai imbalan atas sampah anorganik yang disetorkan dan lingkungan tinggal yang lebih kondusif karena polusi akibat sampah anorganik berkurang. Dalam jangka panjang, biaya yang dikeluarkan pemerintah untuk mengatasi tumpukan sampah di tempat pemrosesan akhir (TPA) juga dapat berkurang. Pengurangan biaya yang terjadi dapat dialokasikan dalam anggaran peningkatan kualitas TPA. Selain dampak positif yang ditimbulkan, kendala sosial berpotensi muncul jika bank sampah dan asuransi sampah didirikan tanpa mempertimbangkan pemangku kepentingan yang lebih luas. Contohnya, tenaga kerja bidang kebersihan yang sedianya rutin mengumpulkan sampah, mungkin akan mengalami penurunan pendapatan atau harus beralih profesi. Untuk itu, pada kegiatan literasi, warga tidak hanya mengakses pemaparan tentang pengelolaan sampah anorganik melalui bank sampah dan asuransi sampah, tetapi juga materi tentang potensi dampak negatif dan cara yang diperlukan untuk menyikapinya.

Untuk mencapai tujuan zero-wwewaste lifestyle, dibutuhkan tiga aspek yakni; ketersediaan pasar, praktik sosio-kultural, dan sistem berbasis mesin atau teknologi (Sharma, Bapat, Brandes, Rice, \& Castaldi, 2019). Hal ini sejalan dengan prinsip manajemen sampah (waste management) yang terdiri dari beberapa aktivitas; minimisasi sampah, pengumpulan sampah, pemilahan sampah, perawatan sampah, transportasi dan pembuangan sampah (Horodytska, Valdés, \& Fullana, 2018). Pada program ini, aspek yang menjadi fokus adalah praktik sosio-kultural yang menekankan prinsip gotong royong. Program dilakukan melalui pendekatan edukatif terhadap masyarakat RW 014 Tulusrejo terkait pengelolaan sampah anorganik. Kegiatan ini dilaksanakan melalui beberapa tahapan yang terdiri atas identifikasi sasaran, persiapan materi, penyampaian materi, serta penilaian dan pemberian umpan balik. Tahapan tersebut secara ringkas disajikan pada Gambar 1.
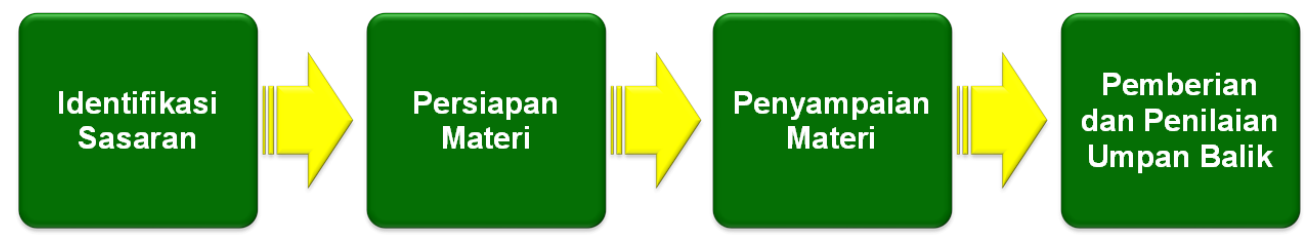

Gambar 1. Metode Pelaksanaan

Pada tahap akhir, warga RW 014 diberi kuesioner untuk menilai kebermanfaatan program penyuluhan ini. Melalui kuesioner ini, tim pengabdian kepada masyarakat bisa memperoleh masukan dari warga terkait program lanjutan untuk menyempurnakan proses pengelolaan sampah secara mandiri oleh warga RW 014. 


\section{HASIL DAN PEMBAHASAN}

Adanya bank sampah dan asuransi sampah diharapkan dapat mengatasi permasalahan sampah dan layanan kesehatan untuk masyarakat. Penyuluhan ini mencakup teori dan pengaplikasiannya; jenis-jenis sampah, pemisahan sampah berdasarkan golongannya, dampaknya terhadap kesehatan, daur ulang dan upaya pendamping lainnya yang dibutuhkan. Penyuluhan ini akan diberikan kepada warga RW 014 Kelurahan Tulusrejo

Acara dilaksanakan selama dua hari yakni pada tanggal 8 dan 9 Agustus 2020 secara daring melalui online meeting room Google Meet. Sebanyak 35 warga Tulusrejo termasuk Ketua RW 12 berpartisipasi dalam forum ini. Agenda ini terselenggara berkat kerjasama Tim Pengabdian Masyarakat FE UM yang diketuai oleh Dr. Nurika Restuningdiah, S.E., M.Si., Ak., CA dan beranggotakan Primasa Minerva Nagari, S.Pd., M.Pd, Fatma Dwi Jati, S.E., M.Acc, dan Aulia Azzardina, S.E., M.Sc yang merupakan para dosen Jurusan Akuntansi Fakultas Ekonomi Universitas Negeri Malang.

Pada hari pertama, materi disajikan oleh seorang praktisi Zero Waste Life Style, Ibu Ullifatul Muyassaro. Ibu Ullifatul mengimbau warga untuk mencintai bumi dimulai dengan mencintai diri sendiri. Hal ini salah satunya dimanifestasikan dalam bentuk pengelolaan sampah rumah tangga secara optimal. Misi ini dieksekusi melalui pemanfaatan limbah rumah tangga menggunakan biopori dan komposter. Kedua pendekatan ini disambut baik oleh warga karena teknik untuk mempelajarinya dirasa mudah, perawatannya dapat dilakukan berbasis swadaya masyarakat dan hasilnya dapat secara berkala dirasakan oleh komunitas terdekat.

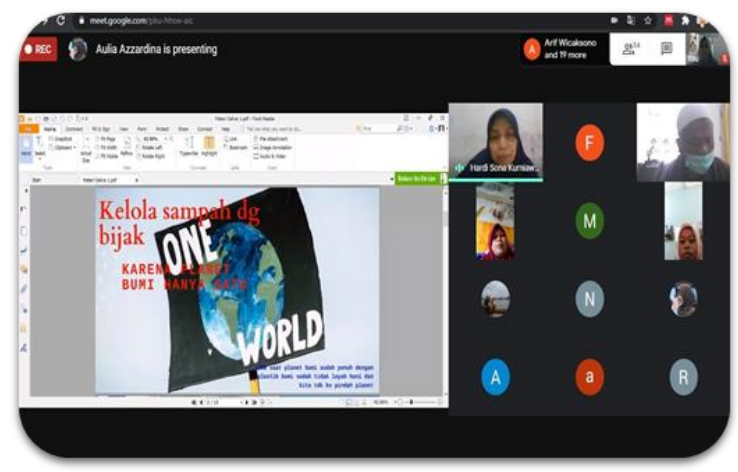

Gambar 2. Penjelasan tentang Bank Sampah

Pada hari kedua, materi disajikan oleh Bapak Ruliyanto Ratno Saputro, seorang pengelola Garbage Clinical Insurance. Wawasan yang dibagikan pada sesi ini menekankan pada potensi cross-funding yang hadir dari pengelolaan sampah plastik yang tepat. Muara dari pengelolaan sampah plastik, terutama berupa botol air minum kemasan tidak hanya berupa pengurangan volume sampah yang tidak dimanfaatkan. Akan tetapi, peningkatan kualitas kesehatan masyarakat juga dapat diupayakan karena sampah plastik yang dihimpun oleh Garbage Clinical Insurance ditebus 
dengan observasi medis pada penyetor limbah plastik oleh tenaga kesehatan yang telah bekerja sama dengan Garbage Clinical Insurance. Melalui diskusi ini, warga menyampaikan ketertarikan untuk dapat berpartisipasi dalam pengelolaan sampah plastik dengan adaptasi konsep cross-funding sederhana demi mencapai kebermanfaatan yang lebih luas.

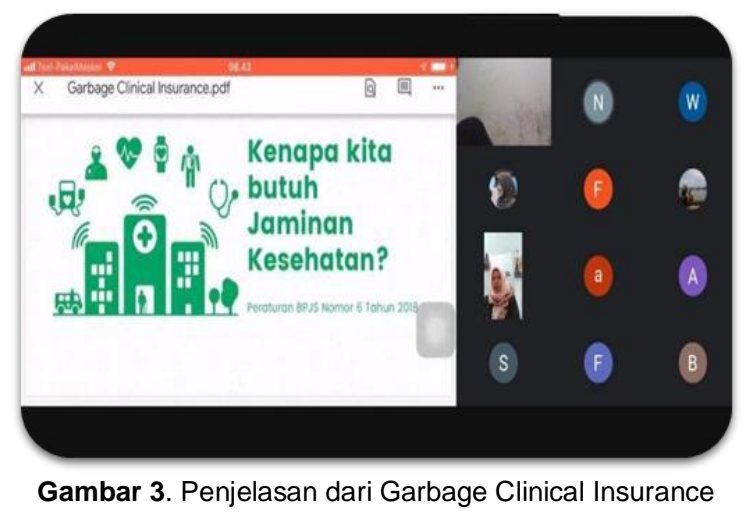

Tim Pengabdian Kepada Masyarakat Fakultas Ekonomi Universitas Negeri Malang berharap realisasi kegiatan ini mendatangkan maslahat yang luas hingga di masa mendatang. Diskusi dan praktik yang telah dilaksanakan diharapkan dapat memantik gagasan berorientasi ramah lingkungan dan penerapan gaya hidup ramah lingkungan pada kawasan yang lebih luas.

Dari penjelasan dan materi yang diterima dari kedua pemateri, warga RW 14 kelurahan Tulusrejo Kota Malang sangat termotivasi untuk terus mengolah sampah rumah tangga menggunakan komposter. Karena tahun sebelumnya warga langsung menerapkan pengolahan sampah. Di tahun ini, perlahan warga juga mempelajari dan ingin melakukan benchmark dengan kelurahan lain yang dtelah dibentuk pengelola bank sampah mandiri di lingkungan tersebut. Nantinya warga RW 14 akan dipandu oleh pemateri untuk membentuk kepengurusan tersebut. Warga RW 14 kelurahan Tulsurejo Kota Malang juga akan mulai mempelajari tentang asuransi sampah agar kebermanfaatkan dari pengelolaan sampah lebih banyak lagi. Dampak dari pelaksanaan pengabdian ini, warga RW 14 kelurahan Tulusrejo Kota Malang menjadi semakin sadar akan pentingnya pengelolaan sampah, baik nantinya akan diolah dan diarahkan ke bank sampah, maupun diarahkan ke asuransi sampah. Dengan semangat dan kesadaran warga, otomatis akan berkontribusi dalam membantu perekonomian secara mikro dan pemenuhan fasilitas kesehatan bagi masyarakat pra sejahtera.

\section{KESIMPULAN}

Sekitar sepertiga dari produksi makanan global terbuang dan berdampak secara ekonomi, lingkungan dan sosial (Principato, Pratesi, \& Secondi, 2018). Mencermati bahwa banyak penduduk yang belum memiliki literasi sampah dengan baik, literasi tentang sampah menjadi sangat 
dibutuhkan dan bermanfaat untuk berakselerasi dengan kebutuhan mengatasai permasalahan lingkungan. Terlebih, setelah banyak bentuk pemanfaatan sampah yang berguna bagi masyarakat, baik dari kalangan menengah ke atas, maupun kalangan pra sejahtera. Pemberian materi tentang Zero Waste Life Style dan Garbage Clinical Insurance diadakan untuk mendukung pemerataan literasi sampah. Melalui kegiatan ini akses terhadap alternatif pemanfaatan sampah baik pada level individu maupun dengan pendekatan gotong royong menjadi lebih dekat. Selanjutnya, melalui kegiatan pengabdian kepada masyarakat, daerah lain dapat terjangkau disertai dengan penawaran solusi yang lebih holistik. Pendekatan yang konsisten pada daerah yang lebih luas diharapkan mampu mendorong kesadaran akan pentingnya pemanfaatan dan pengelolaan sampah. Muara dari pendekatan ini adalah adanya perbaikan perekonomian secara mikro dan juga dukungan terhadap fasilitas kesehatan. Harapannya, secara bertahap masyarakat Indonesia memiliki kecakapan dan kemandirian dalam mengelola sampah pada tingkat individu untuk bergerak secara komunal dalam mendukung kualitas hidup yang lebih baik.

\section{UCAPAN TERIMA KASIH}

Terima kasih kepada Fakultas Ekonomi Universitas Negeri Malang telah memberikan kontribusi langsung kepada tim kami, dan warga RW 14 Kelurahan Tulusrejo Kecamatan Lowokwaru Kota Malang yang telah bersedia menjadi mitra tim pengabdian kami.

\section{DAFTAR RUJUKAN}

Badan Penelitian dan Pengembangan Kesehatan Kementerian Kesehatan Republik Indonesia. (2013). Riset Kesehatan Dasar.

Cervantes-Reyes, A., Núñez-Pineda, A., Barrera-Díaz, C., Varela-Guerrero, V., Martínez-Barrera, G., \& Cuevas-Yañez, E. (2015). Solvent effect in the polyethylene recovery from multilayer postconsumer aseptic packaging. Waste Management, 38(1), 61-64. https://doi.org/10.1016/j.wasman.2015.01.034

CNN. (n.d.). LIPI Tegaskan Bogor Bukan Penyebab Banjir Jakarta. Retrieved January $\quad 8, \quad 2020, \quad$ from https://www.cnnindonesia.com/teknologi/20200107180309-199463264/lipi-tegaskan-bogor-bukan-penyebab-banjir-jakarta

Dobrovszky, K. (2018). Temperature dependent separation of immiscible polymer blend in a melted state. Waste Management, 77, 364-372. https://doi.org/10.1016/j.wasman.2018.04.021

Garofalo, E., Di Maio, L., Scarfato, P., Di Gregorio, F., \& Incarnato, L. (2018). Reactive compatibilization and melt compounding with nanosilicates of post-consumer flexible plastic packagings. Polymer Degradation and Stability, 152 , 52-63. https://doi.org/10.1016/j.polymdegradstab.2018.03.019

Horodytska, O., Valdés, F. J., \& Fullana, A. (2018). Plastic flexible films waste management - A state of art review. Waste Management, 77, 413- 
425. https://doi.org/10.1016/j.wasman.2018.04.023

Indonesian Center for Environmental Law (ICEL). (2019). Implementasi Undang-undang Pengelolaan Sampah.

Kompas. (n.d.). Penjelasan Lengkap Penyebab Banjir Jakarta, Ekstrem hingga Sejarahnya. Retrieved January 8, 2020, from https://www.kompas.com/tren/read/2020/01/03/092500065/penjelasanl engkappenyebabbanjirjakartacurahhuja-terekstremhingga?page=all

Kumparan. (n.d.). Tangani Masalah Sampah, Kota Malang Butuh Rp 90 Miliar Pertahun.

Peraturan Pemerintah Republik Indonesia Nomor 81 tahun 2012 Tentang Pengelolaan Sampah Rumah Tangga dan Sampah Sejenis Sampah Rumah Tangga.

Principato, L., Pratesi, C. A., \& Secondi, L. (2018). Towards Zero Waste: an Exploratory Study on Restaurant managers. International Journal of Hospitality Management, 74(January), 130-137. https://doi.org/10.1016/j.ijhm.2018.02.022

Sahimaa, O., Mattinen, M. K., Koskela, S., Salo, M., Sorvari, J., Myllymaa, T., ... Seppälä, J. (2017). Towards zero climate emissions, zero waste, and one planet living - Testing the applicability of three indicators in Finnish cities. Sustainable Production and Consumption, 10(February), 121-132. https://doi.org/10.1016/j.spc.2017.02.004

Sharma, D. K., Bapat, S., Brandes, W. F., Rice, E., \& Castaldi, M. J. (2019). Technical Feasibility of Zero Waste for Paper and Plastic Wastes. Waste and Biomass Valorization, 10(5), 1355-1363. https://doi.org/10.1007/s12649-017-0109-5

Sudibyo, H., Pradana, Y. S., Budiman, A., \& Budhijanto, W. (2017). Municipal Solid Waste Management in Indonesia - A Study about Selection of Proper Solid Waste Reduction Method in D.I. Yogyakarta Province. Energy Procedia, 143, 494-499. https://doi.org/10.1016/j.egypro.2017.12.716

Tempo. (2019). Menteri Susi Malu RI Penyumbang Sampah Plastik Terbesar Kedua di Dunia.

Undang-undang Republik Indonesia Nomor 18 Tahun 2008 Tentang Pengelolaan Sampah.

Wardhani, D. (2019). Belajar Zero Waste: Menuju Rumah Minim Sampah. Jakarta: Bentala Karya.

Zaman, A. U. (2015). A comprehensive review of the development of zero waste management: Lessons learned and guidelines. Journal of Cleaner Production, 91, 12-25. https://doi.org/10.1016/j.jclepro.2014.12.013

Zaman, A. U., \& Lehmann, S. (2013). The zero waste index: A performance measurement tool for waste management systems in a "zero waste city." Journal of Cleaner Production, 50, 123-132. https://doi.org/10.1016/j.jclepro.2012.11.041 